\title{
Experience-Dependent Plasticity of Adult Rat S1 Cortex Requires Local NMDA Receptor Activation
}

\author{
V. Rema, ${ }^{1}$ M. Armstrong-James, ${ }^{2}$ and F. F. Ebner ${ }^{1}$ \\ 1/nstitute for Developmental Neuroscience, John F. Kennedy Center, Vanderbilt University, Nashville, Tennessee 37203, \\ and ${ }^{2}$ Department of Physiology, Queen Mary Westfield College, London University, London, United Kingdom E1 4NS
}

\begin{abstract}
The effect of blocking NMDA glutamate receptors in adult rat cortex on experience-dependent synaptic plasticity of barrel cortex neurons was studied by infusing D-AP5 with an osmotic minipump over barrel cortex for $5 \mathrm{~d}$ of novel sensory experience. In acute pilot studies, $500 \mu \mathrm{M}$ D-AP5 was shown to specifically suppress NMDA receptor (NMDAR)-dependent responses of single cells in cortical layers I-IV. To induce plasticity, all whiskers except D2 and D1 were cut close to the face $1 \mathrm{~d}$ after pump insertion. The animals were housed with 2 cage mates before recording $4 \mathrm{~d}$ later. This pairing of two whiskers for several days in awake animals generates highly significant biases in responses from D2 layer IV (barrel) cells to the intact D1 whisker as opposed to the cut D3 whisker. D-AP5 completely prevented the D1/D3 surround whisker bias from occur-
\end{abstract}

The whisker to barrel cortex pathway has proven to be a powerful system for studying somatosensory plasticity since its original description by Woolsey and Van der Loos (1970). Many studies on barrel cortex have concerned developmental modifications of the barrel cell clusters consequent to peripheral receptor or infraorbital nerve damage (Ryugo et al., 1975; Killackey et al., 1976, 1978; Woolsey and Wann, 1976; Pidoux et al., 1980; O'Leary et al., 1995). Recently, however, barrel cortex has been shown to exhibit activity-dependent plasticity of physiological responses even in adult rats (Delacour et al., 1987; Diamond et al., 1993; Armstrong-James et al., 1994; Dykes, 1997). In addition, several laboratories have shown adult barrel column plasticity using deoxyglucose (Hand, 1982; McCasland et al., 1991; Kossut et al., 1993; Siucinska and Kossut, 1994; Jablonska et al., 1996; Melzer and Smith, 1997) and optical imaging (Masino and Frostig, 1995) methods. In our laboratories we find substantial modifications in response profiles of barrel cells in all layers of adult cortex after 1-30 d of innocuous bias in sensory activity by simply trimming all but two whiskers ["whisker-pairing plasticity" (WPP)] (Diamond et al., 1993; Armstrong-James et al., 1994).

A current question is whether any commonalties exist between mechanisms supporting long-term potentiation (LTP) and those necessary for WPP. In CA1 hippocampal slices and rat S1/M1 neocortical neurons, induction of LTP is heavily dependent on voltage-dependent NMDA receptor (NMDAR) activation (Ascher and Nowak, 1987), which by contrast is not necessary for

\footnotetext{
Received April 10, 1998; revised Sept. 17, 1998; accepted Sept. 21, 1998.

This work was supported by National Institutes of Health Grants NS-25907 and NS-13031. We thank Ms. Anita Sankaran for expert assistance with the histology.

Correspondence should be addressed to V. Rema, Institute for Developmental Neuroscience, Box 152 Peabody Mailroom, Vanderbilt University, Nashville, TN 37203.

Copyright (ㄷ 1998 Society for Neuroscience $\quad 0270-6474 / 98 / 1810196-11 \$ 05.00 / 0$
}

ring in the D2 barrel cells ( $p>0.6$ for D1 $>$ D3, Wilcoxon). Fast-spike and slow-spike barrel cells were affected equally, suggesting parity for inhibitory and excitatory cell plasticity. D-AP5 only partially suppressed the D1/D3 bias in supragranular layers (layers II-III) in the same penetrations $(p<0.042$ for D1 > D3). In control animals, the inactive L-AP5 isomer allowed the bias to develop normally toward the intact surround whisker $(p<0.001$ for D1 $>$ D3) for cells in all layers. We conclude that experience-dependent synaptic plasticity of mature barrel cortex is cortically dependent and that modification of local cortical NMDARs is necessary for its expression.

Key words: cortical plasticity; barrel field cortex; whisker pairing; glutamate receptors; NMDA receptor; AP5 normal synaptic transmission (Artola and Singer, 1987; Bliss and Collingridge, 1993; Bear, 1996b). Unlike neurons studied in slices of hippocampus or neocortex, however, both normal sensory cortical transmission and spontaneous activity in intact neocortex is substantially NMDAR-dependent in adult rats (ArmstrongJames et al., 1993) and adult cats (Tsumoto et al., 1987; Miller et al., 1989; Hicks et al., 1991). In previous studies on barrel cortex, we have established that sensory responses in layers I-III to principal whisker (PW) stimulation are virtually completely suppressed by D-AP5 iontophoresis at levels specific to NMDAR antagonism. However, as illustrated in Figure 1, responses of layer IV cells are partially dependent on NMDAR activation (Armstrong-James et al., 1993). Specifically, activity evoked at $\leq 8$ msec in layer IV by monosynaptic thalamocortical projections is entirely unaffected by D-AP5 levels that are adequate to block NMDAR activity but is suppressed by DNQX or CNQX, which are specific blockers of AMPA receptors. Spike activity evoked at latencies exceeding $10 \mathrm{msec}$ is virtually completely suppressed by D-AP5, whereas activity at intermediate latencies of $8-10 \mathrm{msec}$ is partially suppressed by AP5 and eliminated by DNQX. These results indicate a shared regulation of spike discharge through NMDA and AMPA receptors for responses to the PW for most cells in rat SI cortex. On the other hand, sensory activation of cortical cells by whiskers forming the surround excitatory receptive field (SRF) is $80-100 \%$ dependent on NMDAR activation (Armstrong-James et al., 1993) (Fig. 1).

In the present study, we have suppressed NMDAR-dependent neuronal responses in layers I-IV of barrel cortex for $4 \mathrm{~d}$ while leaving non-NMDAR receptor-dependent discharge largely unaffected in these layers. We show first that sensory transmission involving NMDARs is crucial to the manifestation of neocortical experiential plasticity and second that expression of this plasticity 

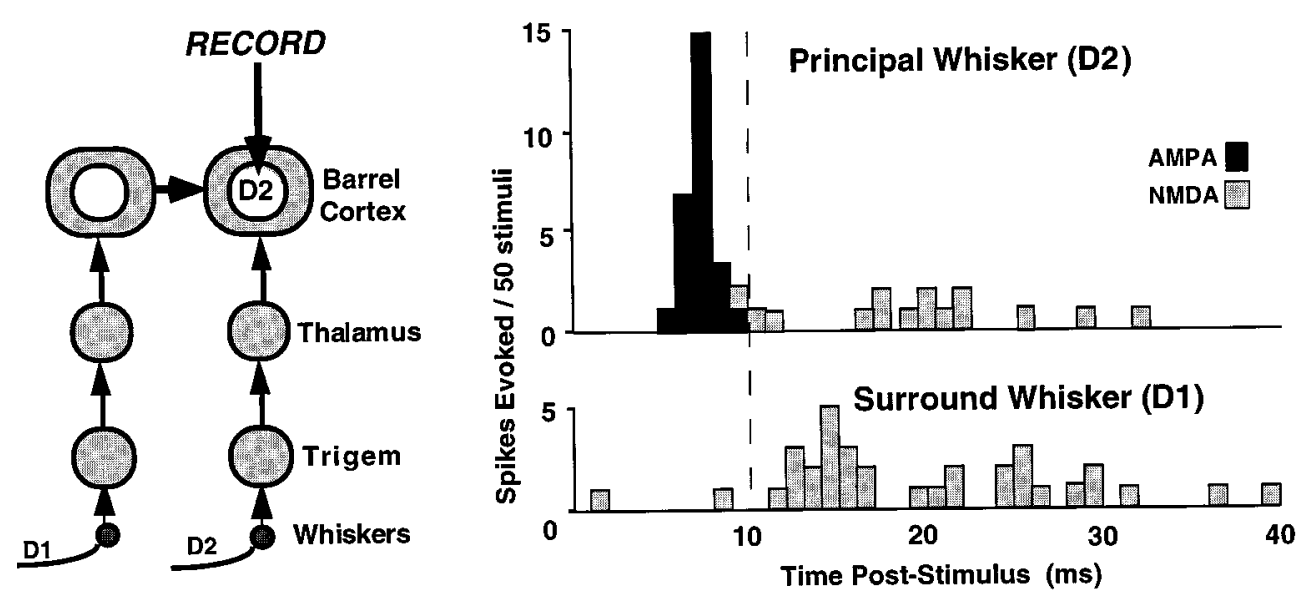

Figure 1. Dependence of cortical responses on NMDA and/or AMPA receptors. Diagram on the left shows the sensory pathway from the whiskers to their respective barrel in cortex with synaptic relays in the brainstem (Trigem) and thalamus. Poststimulus time histograms (right) illustrate the effect of glutamate receptor blockers on different components of typical responses of D2 barrel column cells to stimulation of the principal (D2) or one of the surround D-row (D1) whiskers (M. Armstrong-James, E. Welker, C. A. Callahan, unpublished data). Data represent probabilities of spike discharges and their relative AMPA and NMDA dependence as a function of time poststimulus. Note that short-latency spikes ( $<8$ msec poststimulus) are heavily dependent on AMPA receptor transmission, whereas longer-latency spikes ( $>10$ msec poststimulus) depend on NMDAR transmission.

is consequent to activity-dependent modifications of local cortical circuitry.

\section{MATERIALS AND METHODS}

Animals. A total of 29 adult male Long-Evans rats were used in this study. Initial, acute experiments were performed on 16 animals to achieve a satisfactory AP5 delivery protocol. For the final experiments, nine experimental animals and four control animals were used for analysis of plasticity. All animals were between 2 and 3 months old.

Implantation of osmotic minipumps. Surgery for implanting the pumps was performed using aseptic procedures under Nembutal anesthesia (50 $\mathrm{mg} / \mathrm{kg}$ ). All experimental and control animals had osmotic minipumps implanted that contained $200 \mu \mathrm{l}$ of $500 \mu \mathrm{M}$ active D-isomer of 2-amino-5 phosphonopentanoic acid (D-AP5) or the inactive L-isomer (L-AP5) of the NMDAR antagonist delivered at the rate of $1 \mu \mathrm{l} / \mathrm{hr}$. Both D-AP5 and L-AP5 were purchased from Tocris. Before surgery stock solutions of D-AP5 and L-AP5 at $10 \mathrm{~mm}$ concentration were prepared in artificial CSF (aCSF) and stored as aliquots at $-20^{\circ} \mathrm{C}$. One aliquot was diluted to 500 $\mu \mathrm{M}$ with aCSF and used for one animal. One to $2 \mathrm{hr}$ before surgery the model 2001 Alzet minipumps were filled completely with either D- or L-AP5 solution, attached to the tubing and cannula, and immersed in sterile saline until implantation. The anesthetized rat was placed in a headholder, the soft tissues were retracted from over the calvarium, and a small hole was drilled with a fine dental burr at $2 \mathrm{~mm}$ posterior and 4 $\mathrm{mm}$ lateral to Bregma. This placed the cannula over the dura $\sim 1-2 \mathrm{~mm}$ medial to the D2 barrel column. Care was taken to prevent the cannula from puncturing the dura while it was held in place with a micromanipulator and cemented to the skull. The pump with the tubing attached was inserted into a subcutaneous cavity created by blunt dissection of the connective tissue between the scapulae. The investigators doing the recording were blind to whether a given animal received the active or inactive isomer. There was no observational difference in behavior between animals receiving the D-isomer or L-isomer of AP5.

Whisker pairing. "Whisker pairing" (Armstrong-James et al., 1994) was initiated $\sim 16 \mathrm{hr}$ after the pump was implanted to allow a sufficient concentration of drug to be present at the onset of whisker trimming. All whiskers, except D1 and D2, were trimmed close to the skin. After trimming, the animal was placed in a cage with two other cage mates for $3 \mathrm{~d}$ without further manipulation. Animals having their whiskers trimmed in this way are defined as "whisker-paired" animals (Diamond et al., 1993; Armstrong-James et al., 1994). The spared whiskers are called "paired" or "intact" whiskers, whereas the cut whiskers are called "cut" or "unpaired" or "trimmed" in the text. After trimming, the animals appeared to explore and to "whisk" in the normal manner, and they showed no preference for running against a circular wall in any particular direction (M. E. Diamond, M. Armstrong-James, and F. F. Ebner, unpublished observations). On the evening of the fourth day the pump was removed, and $\sim 14 \mathrm{hr}$ later (on day 5) cortical responses were recorded.

Anesthesia and surgery. For single-unit neurophysiology, all animals were anesthetized with urethane (1.5 gm/ $\mathrm{kg}$, i.p.; $25 \%$ solution in water). When a surgical level of anesthesia was achieved, the rat's head was placed in a stereotaxic apparatus. Body temperature was maintained at $36^{\circ} \mathrm{C}$ by a rectal thermistor electronically controlling a circulating water heating pad under the animal. Cortex was exposed from 4 to $7 \mathrm{~mm}$ lateral to the midline and from 0 to $4 \mathrm{~mm}$ posterior to Bregma to access the D2 barrel. Because anesthetic level profoundly affects response characteristics (Armstrong-James and George, 1988), anesthesia was maintained by supplementary urethane injections (10\% original dose) to maintain burst rates from layer $\mathrm{V}$ neurons at two to four bursts/sec. This rate has been shown to be characteristic of stage III slow-wave sleep and light anesthesia (Armstrong-James et al., 1985; Fox and Armstrong-James, 1986). Under these conditions respiration was regular $(80-110$ breaths/min in nearly all animals), and spontaneous limb and eyelid movements were absent; protraction of whiskers did not occur and whisking movements were absent. Typically, long-latency and sluggish hindlimb withdrawal could be induced with very firm, maintained pressure on the hindfoot.

Electrophysiology and data collection. Responses from single-unit locations were recorded using carbon fiber microelectrodes (ArmstrongJames and Millar, 1979; Armstrong-James et al., 1980). Locations were later identified histologically as being within the D2 barrel column for inclusion in the study. Microelectrodes were advanced with tridimensional microdrives with an accuracy of $5 \mu \mathrm{m}$ in all three dimensions. The positions of all penetrations were recorded and correlated with the subpial depths of neurons. Penetration of the subarachnoid space was determined optically by observing the black tip of the microelectrode and additionally by an increase of noise from the electrode ( $\sim 50 \%$ increase). Minimal dimpling of the cortical surface occurs with the slender profile of these electrodes; consequently, on egress of the microelectrodes, cell positions were invariably accurate to within $25 \mu \mathrm{m}$. Penetrations typically were distributed across the D2 barrel from D1 to D3 barrels. The D2 barrel was located by the knowledge that barrel cells invariably respond at shortest latency $(<8-10 \mathrm{msec})$ to their principal (in this case D2) whisker (Armstrong-James and Fox, 1987; ArmstrongJames et al., 1992, 1994). Receptive fields of neurons from the D2 column were analyzed by stimulating the D2 (principal) whisker and two immediately adjacent D-row surround whiskers, D1 and D3. Neurons were selected by clear isolation of action potentials using a time-amplitude window discriminator (Bak Instruments). The spike durations of all neurons were measured and stored for off-line identification of spike duration. A piezoelectric stimulator was used to deliver standardized 3 msec duration, $300 \mu \mathrm{m}$ upward deflections of each whisker. Responses evoked by each whisker were assessed by averaging poststimulus time histograms (PSTHs) to 50 trials delivered at a rate of one per second. Discriminated spike logic pulses were collected into $1 \mathrm{msec}$ bins using a CED 1401 Plus processor (Cambridge Electronic Design 1401 plus) controlled by a 486 PC (Compaq) and analyzed with the Spike 2 language (Cambridge Electronic Design) using in-house protocols.

Histology and identification of recording site. Cortical recording sites were marked in vivo by passing a negative DC current of $1 \mu \mathrm{A}$ for $5-8 \mathrm{sec}$ on termination of recordings in a penetration. This current produced a spherical microlesion, $\sim 50-80 \mu \mathrm{m}$ in diameter, easily visible in histological sections reacted for cytochrome oxidase (CO) histochemistry. For two penetrations in each animal, two lesions per track were made to 


\section{Center Receptive Field whisker}

Figure 2. Suppression of whisker-driven responses of cells in layers I-IV after perfusion of barrel cortex with D-AP5 at concentrations of 0.1-10 mM. Epidural perfusion was maintained for a minimum of $6 \mathrm{hr}$. Findings are from 12 animals tested at concentrations of $0.01 \mathrm{~mm}(n=1), 0.1$ $\mathrm{mm}(n=2), 1.0 \mathrm{~mm}(n=3), 2.0 \mathrm{~mm}(n=2), 4 \mathrm{~mm}(n=$ $2)$, and $10 \mathrm{~mm}(n=2)$ D-AP5. Responsive sites were initially categorized by testing for response to any whisker at midlayer depths $[\sim 300,400$, and $650 \mu \mathrm{m}$ subpial for layers II/III and IV (Armstrong-James and Fox, 1987)]. The depth of the first cell was logged and tested with our standard protocol of 50 deflections of individual whiskers to construct PSTHs. Top, Responses to deflections of center receptive whiskers were almost completely suppressed in layer IV by concentrations of 2,4 , and $10 \mathrm{mM}$ D-AP5, but only partially by concentrations of $0.1-1.0 \mathrm{~mm}$ and not at all by $0.01 \mathrm{~mm}$. Responses of cells in layer III were also unaffected by $0.01 \mathrm{~mm}$, but completely suppressed by $1.0 \mathrm{~mm}$ D-AP5. Bottom, Responses to deflection of adjacent in-row surround receptive field whiskers were completely suppressed in layer IV by concentrations of $2.0-10 \mathrm{~mm}$ D-AP5 but only partially by concentrations of 0.1-1.0 mM D-AP5 and not at all by a concentration of 0.01 mM. Responses of cells in layer III were unaffected by 0.01 $\mathrm{mm}$, only partially by $0.1 \mathrm{~mm}$, but completely suppressed by $1.0 \mathrm{mM}$ D-AP5.

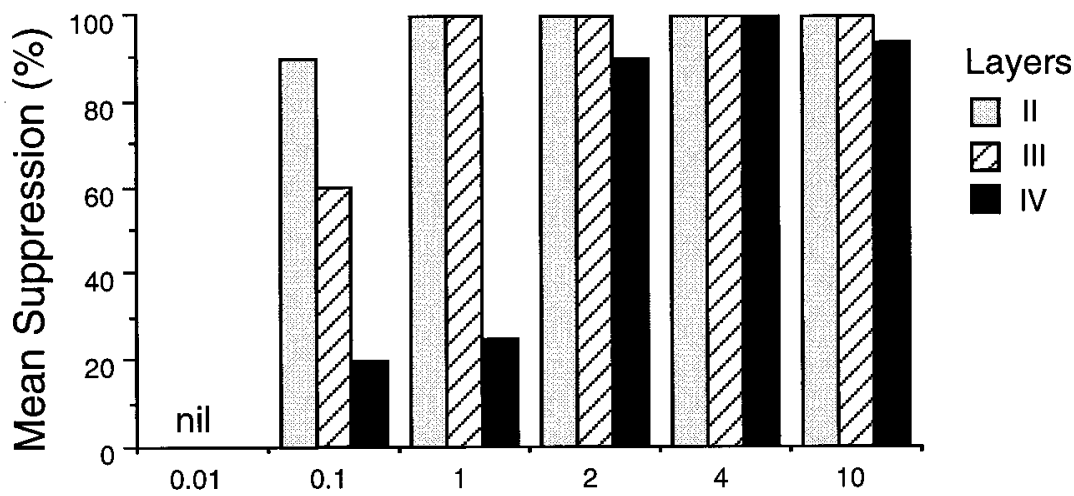

Adjacent Surround Receptive Field Whisker

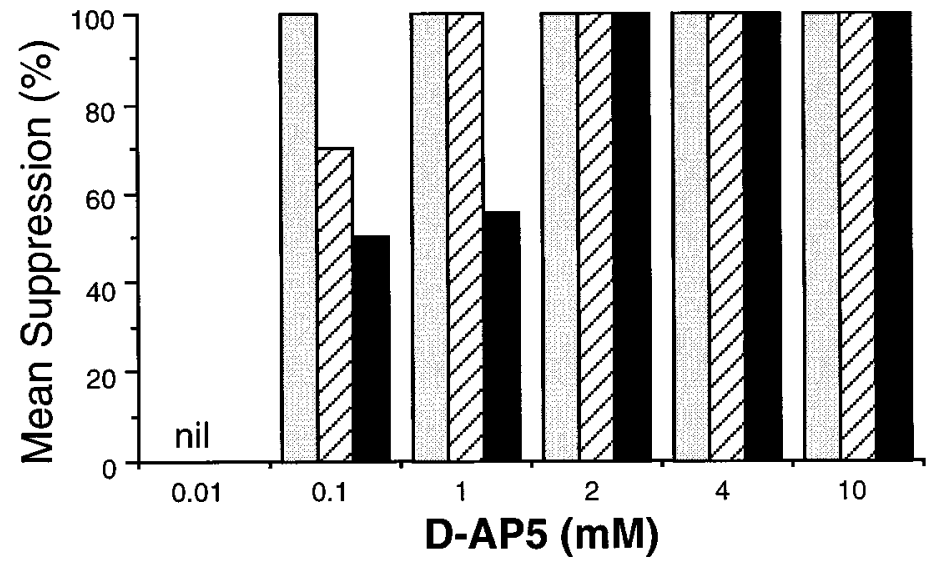

identify penetration locations and to correlate in vivo depth with laminae identification in histology sections. On completion of recordings, animals were overdosed with Nembutal and perfused transcardially with saline ( $0.9 \%$ sodium chloride) followed by phosphate-buffered $4 \%$ paraformaldehyde. Brains were saturated in $20 \%$ sucrose and then $30 \%$ sucrose, and the cortex was flattened, sectioned tangentially, and stained for cytochrome oxidase activity (Wong-Riley and Welt, 1980) for locating barrels and microlesion sites. A penetration was considered to be within the D2 barrel column if the recording sites were judged to be localized within or above or below the bounds of barrel D2 as defined by the appropriate patch of high CO activity in layer IV. All penetrations located in the septa separating barrel columns or within barrel territories other than D2 were excluded from analysis.

Data analysis. In common with previous studies (e.g., ArmstrongJames and Fox, 1987; Armstrong-James et al., 1992), neurons collected from depths of $450-800 \mu \mathrm{m}$ in vivo almost without exception were within defined barrel territory as observed by high $\mathrm{CO}$ density areas. Above these locations neurons were defined as layer II-III cells and grouped as a single class. All data were analyzed according to location either in layers II-III or layer IV as identified above. Neurons collected below the depth of $850 \mu \mathrm{m}$ were considered to be in the infragranular layers, mainly layer $\mathrm{V}$.

Counts of spikes generated $100 \mathrm{msec}$ poststimulus were adjusted for spontaneous activity, by subtracting the mean count per bin for spontaneous activity collected in the $50 \mathrm{msec}$ before the stimulus from each poststimulus bin count. PSTHs for some purposes were grouped into several intervals or "epochs" for PSTH epoch analysis: namely, 3-10, $10-20,20-100 \mathrm{msec}$. Spikes within $3 \mathrm{msec}$ poststimulus were excluded as being too early to be responses evoked by whisker stimulation. Latency histograms were constructed from the first spike poststimulus for each trial, the bin with the highest count of evoked spikes being registered as the modal latency resolved from $1 \mathrm{msec}$ bins. Statistical analysis of data were by application of Mann-Whitney $U$ tests or Wilcoxon tests where appropriate.
Immunocytochemistry. To determine whether there were changes in the level of NMDAR1 protein at the site of recording, brains from two animals superfused with D-AP5 were immunoreacted with antibodies to NMDAR1 using the protocol described in Rema and Ebner (1996a) and compared with controls. Animals were deeply anesthetized with sodium pentobarbital and then perfused transcardially with PBS followed by $4 \%$ paraformaldehyde in PBS. The brains were then removed and cryoprotected in $30 \%$ sucrose and sectioned at $40 \mu \mathrm{m}$ thickness. Sections were immunoreacted with NMDAR1 antibody (AB59) for $48 \mathrm{hr}$ at $4^{\circ} \mathrm{C}$. The reactions were visualized using the diaminobenzidine method.

\section{RESULTS}

\section{Epidural infusion of AP5}

For the present study we needed to determine an optimal concentration of D-AP5 to be superfused over the cortical surface with an osmotic minipump (Alzet). To arrive at the most effective concentration of AP5 to place in the minipump from where it would be released medial to the barrel field, experiments were performed using different concentrations of D-AP5 in the minipump (Fig. 2). It was found that superfusion of D-AP5 at higher concentrations $(2-10 \mathrm{~mm})$, while effective in eliminating long-latency (NMDA-dependent) responses from layer IV cells, usually caused significant or total suppression of short-latency ( $\leq 8 \mathrm{msec}$ ) spikes from cells at up to $650 \mu \mathrm{m}$ depth (middle layer IV), suggesting inappropriate and nonspecific impairment of AMPA receptor transmission. Concentrations of D-AP5 at $10 \mu \mathrm{M}$ were entirely ineffective in suppressing either late or early responses of layer IV cells or even cells at 100-200 $\mu \mathrm{m}$ depths (layers I-II). Concentrations at $100 \mu \mathrm{M}$ superfused for periods of 


\section{VPM Cells}

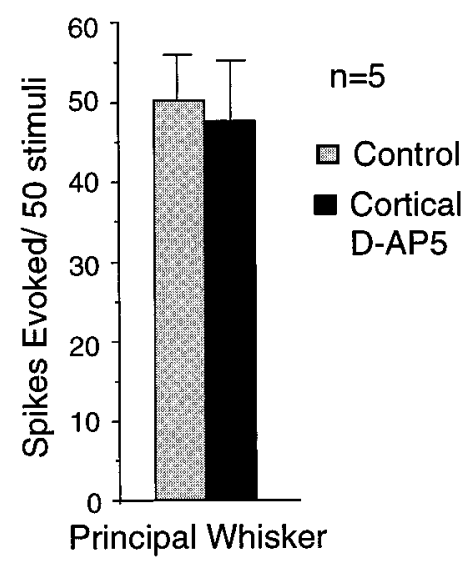

Figure 3. Mean responses of five cells in the ipsilateral ventral posterior medial (VPM) nucleus of the thalamus to 50 stimuli applied to each cell's principal whisker before (stippled) and immediately following $5 \mathrm{hr}$ (solid black) perfusion of $500 \mu \mathrm{M}$ D-AP5 over barrel cortex. Before drug application, VPM cells were sampled at five sites in one penetration through VPM using coordinates of Armstrong-James and Callahan (1992). These same sites $( \pm 75 \mu \mathrm{m})$ were then retested after D-AP5 application. Responses of VPM cells to principal whiskers did not differ significantly before and after $5 \mathrm{hr}$ exposure to $500 \mu \mathrm{m}$ D-AP5 to cortex. Surround whisker responses were maintained in both cases but varied as a function of the recording site in the nucleus, so they cannot be directly compared.

up to $5 \mathrm{hr}$ also typically left cells at $450-600 \mu \mathrm{m}$ unaffected, although these concentrations did reduce evoked activity of layer II cells found at depths of up to $300 \mu \mathrm{m}$ below the cortical surface. D-AP5 superfused epidurally at a concentration of $500 \mu \mathrm{M}$ was found to satisfy the criteria required.

When the microelectrode was advanced to the thalamic ventral posterior medial (VPM) nucleus, responses relayed there to principal whisker stimulation were unaltered after superfusion of D-AP5 as shown in Figure 3. As judged independently against previous findings where VPM responses are exquisitely sensitive to excitatory amino acid antagonists and other drugs (Salt and Eaton, 1988; Armstrong-James et al., 1991), VPM responses appeared unaffected.

In further support of the contention that superfused $500 \mu \mathrm{M}$ AP5 did not diffuse to the thalamus, we have found in previous studies that much higher concentrations of depressant drugs or ions superfused over the barrel cortex cause no diminution of responses from VPM whisker-relay neurons (Diamond et al., 1992). As a consequence of these findings taken together, all superfusion experiments on D1-D2 whisker-paired animals using the Alzet minipump were performed using $500 \mu \mathrm{M}$ concentrations of either D-AP5 (for experimental animals) or the inactive isomer L-AP5 (for controls).

Figure 4 shows the outcome of a representative experiment in which $500 \mu \mathrm{M}$ D-AP5 was superfused over the dura, and responses from D4 barrel neurons, $1.5 \mathrm{~mm}$ away, were followed over a period of $3 \mathrm{hr}$ of drug exposure. The two examples are from separate penetrations that were located at subcortical depths of 615 and $680 \mu \mathrm{m}$ (layer IV). For the first cell (Cell $A$ ), it is evident that substantial suppression of discharges at latencies $>10 \mathrm{msec}$ poststimulus develops within a few minutes of D-AP5 superfusion, and that continued exposure to D-AP5 at this level for $2 \mathrm{hr}$ holds suppression of NMDAR-dependent discharge at $\sim 60 \%$.
Furthermore, discharges evoked at latencies of $<8 \mathrm{msec}$ are entirely unaffected by D-AP5 for the course of the exposure. Because earlier studies have shown that all principal whiskerevoked discharges at latencies $<8 \mathrm{msec}$ are entirely dependent on AMPA receptor activation (Armstrong-James et al., 1993), we conclude that AMPA receptor-dependent discharges were unaffected.

\section{D1-D2 whisker-paired animals}

In the second phase of this study all experiments were performed on animals with all whiskers cut except D1 and D2 for a period of $4 \mathrm{~d}$ (whisker-paired animals). In normal, untreated animals the cell population within the D2 barrel column can be expected to exhibit symmetrical, D-row surround whisker receptive fields such that the mean response magnitudes to D1 and D3 whiskers are equal. In normal adult D1-D2 whisker-paired animals, (1) the response to the principal whisker, D2, becomes significantly larger, and (2) the surround response to the intact D1 whisker is potentiated, thereby biasing the SRF (Diamond et al., 1993; Armstrong-James et al., 1994; Rema and Ebner, 1996b; Sachdev et al., 1998). The findings below compare receptive field modifications of D2 barrel column cells for experimental (D-AP5 active isomer) and control (L-AP5 inactive isomer) epidurally superfused animals.

\section{Distribution of cells studied}

For these experiments, the loci of penetrations in the D2 barrel column were regulated to ensure that their positions were not skewed toward either the D1 or the D3 barrel. Attempts were made to locate penetrations successively across the width of the D2 barrel between barrels D1 and D3. This procedure was used to avoid a small inherent bias of SRF responses to one or other of whiskers D1 or D3, which might arise from too many penetrations being on one side of the barrel (Armstrong-James et al., 1994). The spatial distribution of all penetrations across the D2 barrel column in the two categories of animals (control and experimental) are shown in Figure 5, and they demonstrate that for control and experimental animals penetrations were not skewed toward either the D1 or the D3 barrel.

Typically, in each penetration four to eight cells were studied for response to brief $(3 \mathrm{msec})$ deflections of the principal whisker (D2) and the immediately surrounding D-row whiskers (D1 was always the intact D-row whisker, and D3 always the trimmed D-row whisker). Within the D2 barrel column we restricted our analysis to responses from cells located at depths of $0-800 \mu \mathrm{m}$ spanning the first four cortical layers (see Materials and Methods). For the bulk of the findings presented below, cells were grouped for separate analysis by being designated within supragranular (SG) layers II-III (0-450 $\mu \mathrm{m}$ depths) or within granular layer IV barrels $(>450$ to $<800 \mu \mathrm{m})$.

\section{Effect of D-AP5 on layer IV barrel cell plasticity}

The effect of $4 \mathrm{~d}$ of epidural perfusion of D-AP5 or L-AP5 over the barrel cortex was computed from PSTH data for the two groups. Responses from 115 cells from experimental animals and 51 cells from control animals were analyzed, all of which were located in the D2 barrel. These cells were located within the same penetrations as those described below for superficial (layers IIIII) cells. The mean response magnitudes to peripheral stimulation of the D-row whiskers are compared for the two groups of animals in Figure 6. In control animals L-AP5 failed to prevent whisker-pairing plasticity of D2 barrel cells.

In those animals a clear bias developed in response to the intact 
Figure 4. Suppression of long-latency responses by perfusion of $500 \mu \mathrm{M}$ D-AP5 onto cortex. Cells A and B are two neurons analyzed from barrel D4. Cell $A$ shows changes in mean response magnitudes to center whisker D4 and to surround whiskers D3 and D5 during application of $500 \mu \mathrm{m}$ D-AP5 in a normal adult animal. Sequential trials of whisker responses were recorded before and after 20, 50, and $180 \mathrm{~min}$ of exposure to D-AP5. Responses were derived from analysis of PSTH data by accumulating spike numbers into the stacked epochs of various poststimulus durations (inset key). Note that short-latency responses (at 3-8 and $8-10 \mathrm{msec}$ ) show little change in magnitude. These responses in previous studies have been shown to be all $(3-8 \mathrm{msec})$ or mostly $(8-10 \mathrm{msec})$ identifiable with monosynaptic thalamocortical discharge (see Results) and are generated through

AMPA receptors (Armstrong-James et al., 1993). Cell B was a recorded some 20 min after Cell A in an adjacent penetration during a continuation of the perfusion (D-AP5). A very substantial recovery to normal values for cells in layer IV occurred 25 min after removal of D-AP5. The penetration sites in each case were protected from the superfusate by a small well, constructed from dental cement. Superfusion was $\sim 1-3 \mathrm{~mm}$ distant to the D4 barrel column.
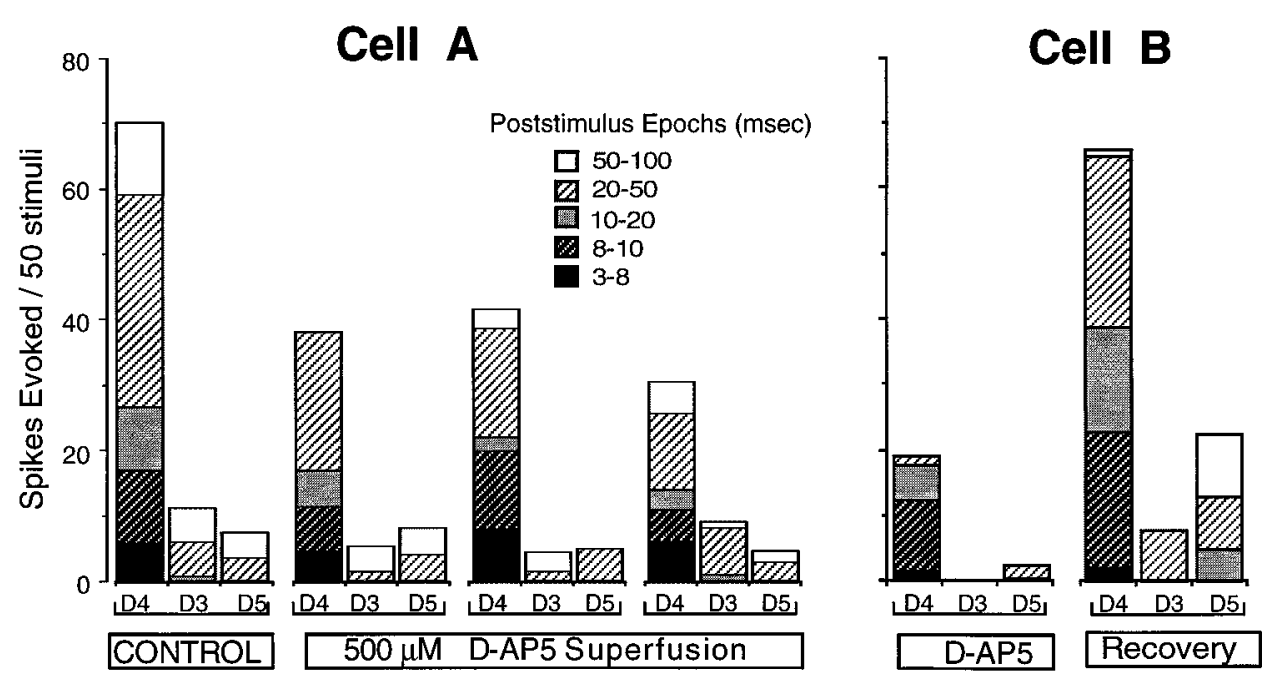
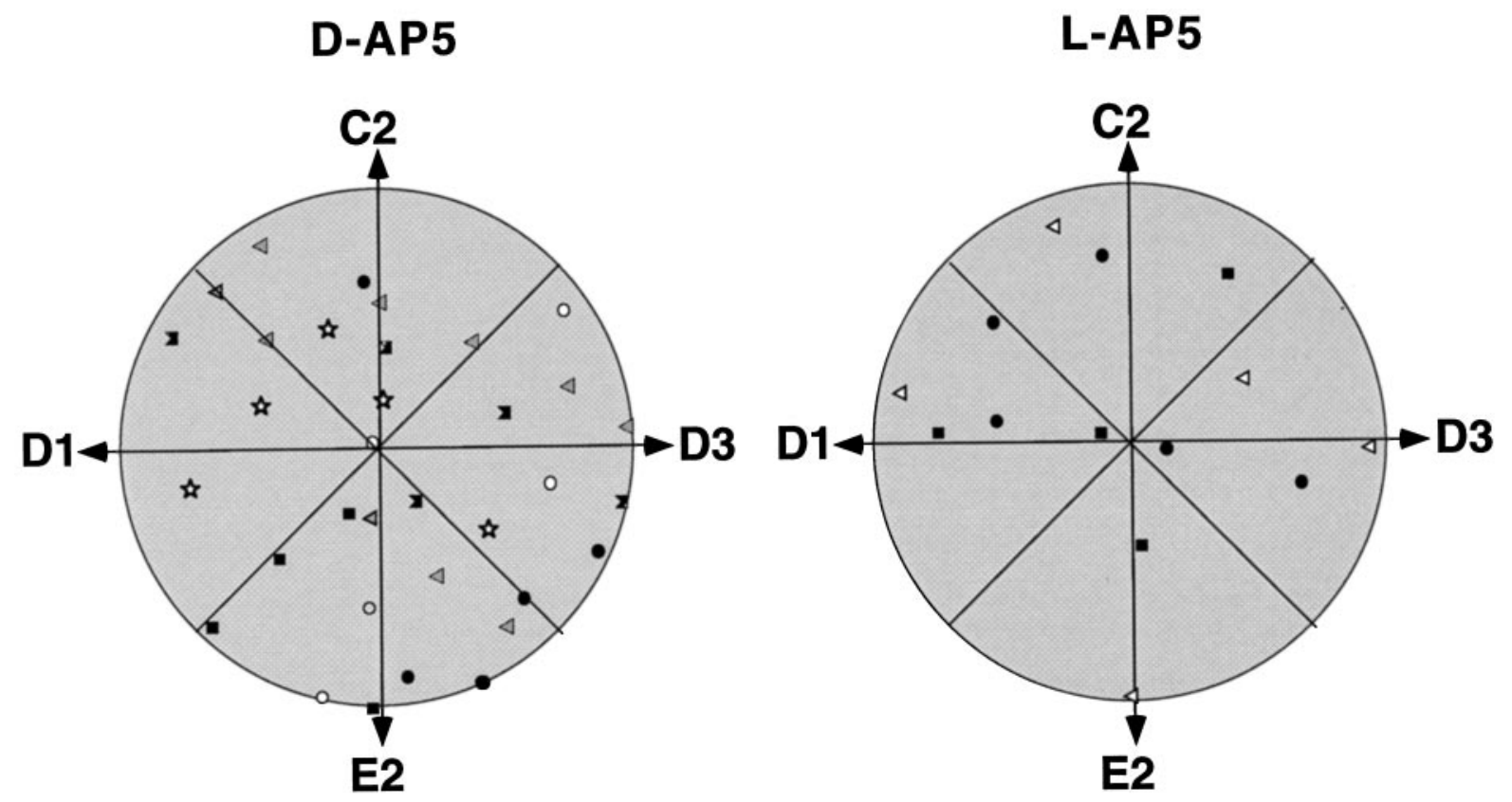

Figure 5. Diagram representing distributions of the penetrations by segment of the D2 barrel for cells used for analysis in subsequent figures for D-AP5 (left) and L-AP5 animals (right). The penetrations in each group of animals were quite evenly spread through the barrel in reference to their positions in the horizontal axis. Arrows point to the positions of the adjacent D1 or D3 barrel in the D-row. Distributions were not significantly different in left and right barrel halves. It was desirable to obtain an even distribution with respect to proximity to surrounding barrels because asymmetrical position of penetrations influence mean neuronal responses to surround whiskers D1 and D3 (Armstrong-James et al., 1994).

D1 whisker as compared with the cut D3 whisker after $4 \mathrm{~d}$ of whisker pairing $(\mathrm{D} 1=31 \pm 3.4$; D3 $=17.5 \pm 2.6$; Wilcoxon matched pair; $p=0.019$ ). For experimental animals the attainment of difference in mean response magnitudes between D3 and D1 whiskers was eliminated by $4 \mathrm{~d}$ of D-AP5 exposure, and the small difference that was observed $(22.5 \pm 2.4$ and $24.2 \pm 2.0$ spikes/50 stimuli, D3 and D1, respectively) was not significant (Wilcoxon matched pair; $p=0.689$ ). No significant differences in mean response magnitude were found between responses to D3 whiskers for experimental and control animals (Mann-Whitney $U$ test). Differences between responses to D1 whiskers for experi- mentals and controls were just significant ( $p=0.05$; MannWhitney $U$ test). When cells were compared on a cell-by-cell basis the bias to the paired SRF D1 whisker was prevented completely by D-AP5 exposure (Fig. 7), whereas with control exposure to L-AP5 a profound bias to the paired D1 whisker developed, typical of undrugged (normal) animals.

\section{Fast-spike and slow-spike cells}

In rodent cortex, fast-spike cells with short action potentials constitute a different morphological and functional group from cells with longer action potentials, particularly within layer IV 


\section{Barrel (Layer IV) Cells}

D-AP5

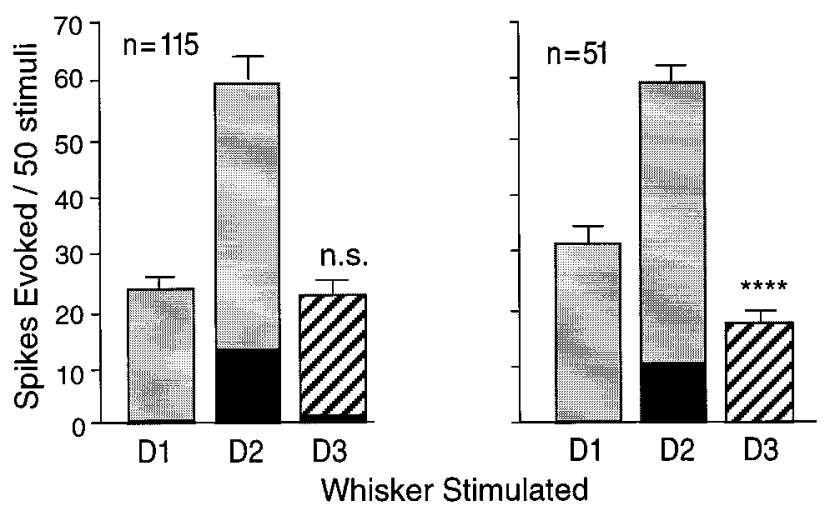

Figure 6. Mean response magnitudes for cells in layer IV of the D2 barrel for control and experimental groups of animals 12-14 hr after stopping perfusion of cortex with the active NMDAR antagonist (D-AP5) or the inactive isomer (L-AP5). Histograms represent mean responses for 115 cells (D-AP5) and 51 cells (L-AP5). Each cell was sampled and analyzed from PSTH data to 50 stimuli applied to each of three D-row whiskers. Error bars represent SEM. Responses to D3 whisker are significantly different in magnitude to D1 whiskers $(* * * * p=0.002$, Wilcoxon matched-pair sample test) for controls. In the experimental animals (D-AP5), responses to D1 and D3 were not significantly (n.s.) different. Shortest latency responses (3-8 msec poststimulus) are indicated by black within the histograms, which illustrate total responses during $100 \mathrm{msec}$ poststimulus (gray stipple $=$ intact whiskers; diagonal stripes $=$ cut whiskers).

(see Discussion). Because strong evidence exists that nearly all fast-spike cells in neocortex are inhibitory interneurons whereas cells with longer duration spikes are predominantly excitatory cells, plasticity for the two groups was evaluated.

Action potential durations were measured in the present study for 98 of the cells in the D2 barrel column $(n=32$ layers II-III; $n=66$ layer IV barrel) whose receptivity to D-row whiskers was tested (Fig. 8). Spikes were classified as slow spikes when $>0.75$ msec in duration and as fast-spikes at durations of $\leq 0.75 \mathrm{msec}$. The distributions of these cells by action potential duration were compared with durations for a larger sample of cells from previous studies (M. Armstrong-James, personal communication). In both studies it is clear that a bimodal distribution of action potential duration exists with the anti-mode at $0.75 \mathrm{msec}$. Figure 9 shows the effects of D-AP5 compared with controls on whiskerpairing plasticity of cells in the D2 barrel for fast and slow spikes separately; data being abstracted from the same database as for layer IV cells in Figure 6 for which spike durations were measured. Two findings are apparent. First, both classes of cells (slow or fast spikes) exhibited a similar behavior to whisker pairing in that they generate similar biases in the receptive field responses toward the paired surround D1 whisker relative to the D3 whisker. D1 responses in controls were significantly greater than unpaired D3 responses for both types of cells (Wilcoxon; $p=$ 0.002 and 0.05 for slow and fast spikes, respectively). Second, D-AP5 perfusion prevented this bias entirely, with no significant differences in response to the paired D1 or cut D3 whisker $(p>$ 0.4 and $p>0.8$ for slow and fast spikes, respectively).

\section{Bias in responses to D1 or D3 by penetration}

A further index of plasticity is generated by examining the proportion of penetrations through the D2 barrel, which exhibited a

\section{Barrel (Layer IV) Cells}
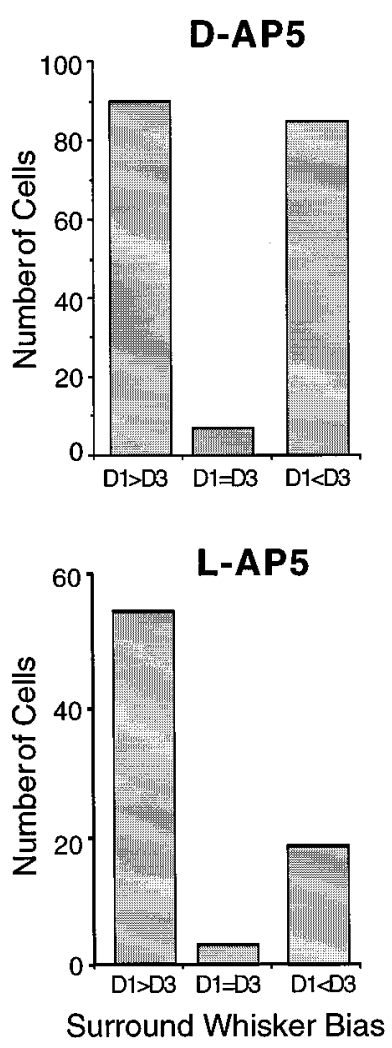

Figure 7. Degree of surround whisker bias for cells in the D2 barrel (layer IV) evaluated on the basis of number of cells responding at greater or lesser response magnitudes to the D1 whisker (paired whisker) relative to the $\mathrm{D} 3$ whisker. $D 1=D 3$ indicates when responses were equal (mean response magnitudes within $\pm 5 \%$ of each other). Exposure to the active D-AP5 isomer eliminated the bias expected after whisker pairing.

bias toward one or other of the D-surround whiskers. For control animals, only $4.5 \%$ of penetrations were biased toward the cut whisker, with $67 \%$ being biased toward the paired surround whisker. By contrast, after treatment with the active isomer D-AP5, the numbers of penetrations biased to one or the other D-surround whisker were similar with $50 \%$ of penetrations being found to be biased to the cut whisker and $41 \%$ to the paired whisker, D1.

\section{Cells in layers II-III (supragranular cells)}

In the supragranular layers of the D2 barrel column, 70 cells in experimental D-AP5-infused animals and 27 cells in L-AP5infused control animals were studied. Because receptive fields of cells in the upper layers differ somewhat by laminar location (Armstrong-James and Fox, 1987; Armstrong-James et al., 1992), it was necessary to establish that laminar distributions were similar for cells in the two groups included in the analysis. The distributions of acceptable cells by depth for those located in layers II-III for experimentals and controls are shown in Figure 10. From this figure it is evident that there was no difference in bias for laminar distributions of cells studied between experimental and control animals.

\section{Effect of D-AP5 on layers II-III (supragranular) cell plasticity}

The effects of $4 \mathrm{~d}$ of epidural superfusion of D-AP5 and L-AP5 over the barrel cortex on mean response magnitudes of cells in 


\section{D-AP5 Perfused Animals}
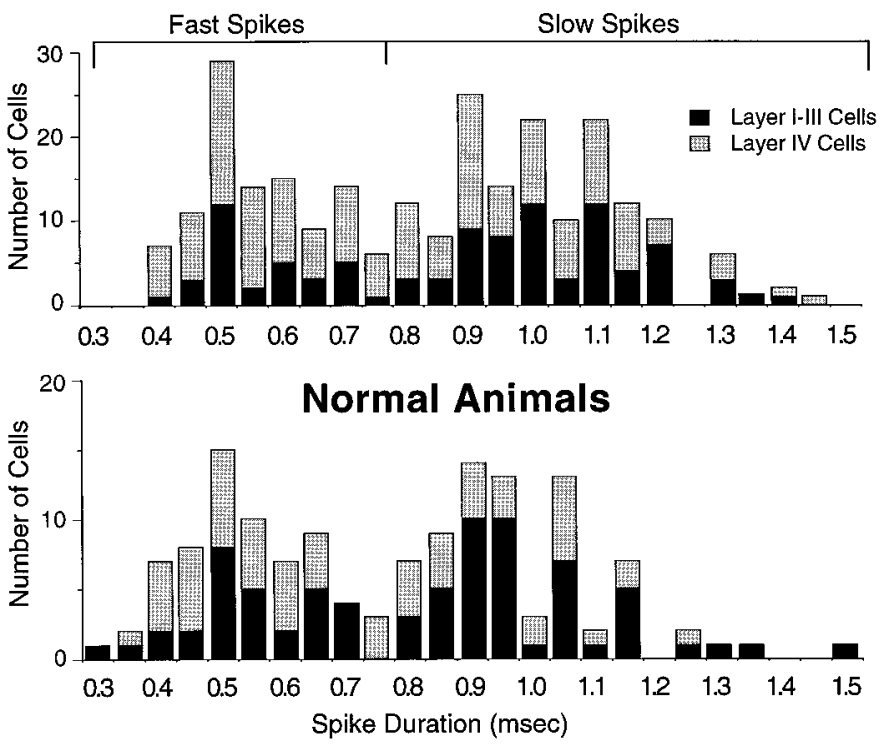

Figure 8. Top, Distribution of spike durations recorded from D-AP5perfused animals for the cells in layers II-III (black bars) and IV (gray bars) of the D2 barrel column used for this study. Note the bimodal nature of the histogram with antimode at $0.75 \mathrm{msec}$. Spike durations were measured on a digital Nicolet storage oscilloscope; traces were delayed by $1 \mathrm{msec}$ for establishing onset. Durations were measured from quiescent zero-crossing onset to repolarization across zero voltage, bandpassed at 0.7-10 kHz. Bottom, Distribution of spike durations recorded for the cells in layers II-III (black bars) and IV (gray bars) of the D2 barrel column. These data were generated in earlier studies on the D2 barrel column in normal animals used for unrelated experiments, where no drugs were used, but conditions were entirely similar. Note the similar bimodal distributions separated at $0.75 \mathrm{msec}$ in the two studies and similar modal values.

superficial layers to deflection of the D-row whiskers are compared for the two groups of animals in Figure 11.

In control animals a clear bias developed in response to the intact D1 whisker compared with the cut whisker D3 after $4 \mathrm{~d}$ of whisker pairing (Wilcoxon matched pair; $p=0.019$ ). The mean response to the intact D1 whisker was close to twice that to the cut D3 whisker in the presence of L-AP5 (19.98 and 10.66 spikes/50 stimuli, respectively), showing a normal development in bias toward the spared surround whisker. For experimental animals the difference in mean response magnitudes to D1 and D3 was less (20.68 and 15.32 spikes/50 stimuli, respectively), although this difference was still just significant (Wilcoxon matched pair; $p=0.048)$. However, no significant difference in mean response magnitude was found between like individual D-row whiskers for experimentals and controls. When cells were compared on a cell-by-cell basis, however, a clear bias to the paired SRF whisker was apparent (Fig. 12). The proportion of cells failing to exhibit a bias to the paired D1 whisker doubled after treatment with D-AP5. Overall the exposure to D-AP5 for $4 \mathrm{~d}$ had no effect on mean D2 response magnitudes when compared with controls.

\section{Spontaneous activity}

Infusion of D-AP5 does not alter the spontaneous activity levels of neurons in layer IV barrels compared with control (1.189 \pm $0.058 \mathrm{~Hz}$ and $1.207 \pm 0.71 \mathrm{~Hz}$ for both D- and L-AP5; $p=0.2317$, Mann-Whitney $U$ ). However, in the supragranular layer II-III neurons there is a reduction in mean spontaneous activity from $1.4 \pm 1.368 \mathrm{~Hz}$ for control L-AP5 cases compared with $1.0 \pm 1.1$ $\mathrm{Hz}$ for D-AP5 experimental cases.

\section{Effect of D-AP5 on the distribution of NMDAR1 subunit}

One of the questions raised by chronic administration of an NMDAR blocker is whether the receptors are dramatically upregulated, downregulated, or changed in distribution along the dendrites over the course of receptor blockade. In three separate cases, after $5 \mathrm{~d}$ of superfusion of $500 \mu \mathrm{M}$ D-AP5 the cortex was immunoreacted for the NMDAR1 subunit. When compared with the control hemisphere, the density of NMDAR1 subunit was not altered, as judged by inspection of the light microscopic slides in these cases.

\section{DISCUSSION}

The principal objective of this study was to establish whether innocuous experience-dependent plasticity of adult cortical neurons was dependent on postsynaptic cortical activity, specifically plasticity generated through NMDAR activation. We have found that $4 \mathrm{~d}$ of epidural superfusion of $500 \mu \mathrm{M}$ D-AP5 entirely prevented experience-dependent plasticity of layer IV barrel neurons. WPP is seen initially as an upward shift in response level to an intact surround and principal whisker (Armstrong-James et al., 1993; Diamond et al., 1993). The procedure did not significantly affect overall spontaneous activity in layer IV neurons and response levels of barrel neurons, which were similar in controls, experimentals, and in previous studies on normal animals in our laboratories (Armstrong-James et al., 1992, 1993; Diamond et al.,
Figure 9. Mean response magnitudes for the cells in the D2 barrel (layer IV) for control and experimental groups of animals divided into fast-spike and slow-spike categories. Note that both fast- and slow-spike cells exhibit similar plasticity after treatment with L-AP5 during pairing and similar total suppression of plasticity in the presence of the active isomer D-AP5 during pairing. For further details, see Figure 6 from which this data were reclassified.
Fast-spike Cells

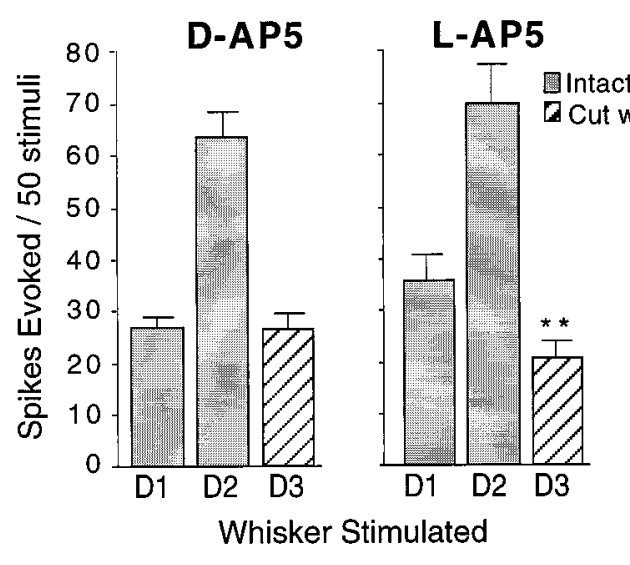

Slow-spike Cells

$$
\text { D-AP5 L-AP5 }
$$

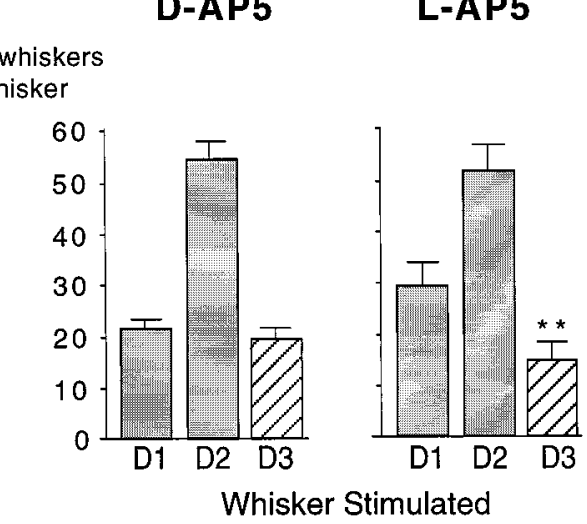




\section{Cell Dist ributions (Layers II/ III)}

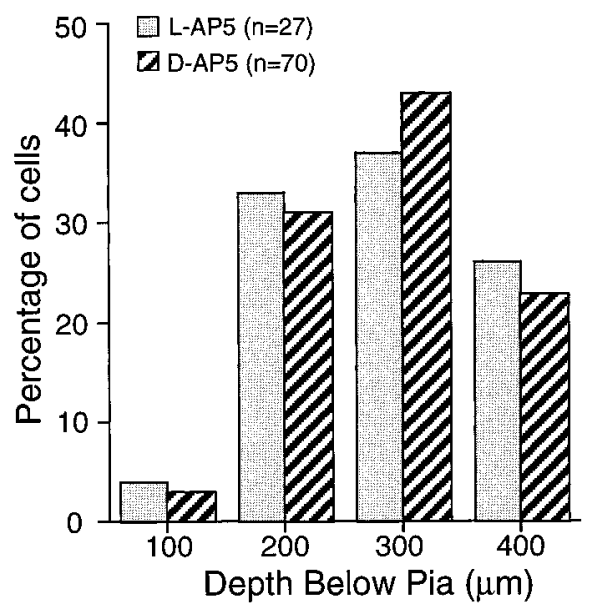

Figure 10. Distributions of cells by depth recorded in the superficial layers of the D2 column, layers II-III (between the cortical surface and $450 \mu \mathrm{m})$. Values 100 to 400 indicate depth $\pm 50 \mu \mathrm{m}$, e.g., $100=50-150$ $\mu \mathrm{m}$. Note similarity of distributions for controls and experimentals, supporting the idea that similar sampling of neurons occurred in each group.

\section{Layer II/III Cells}

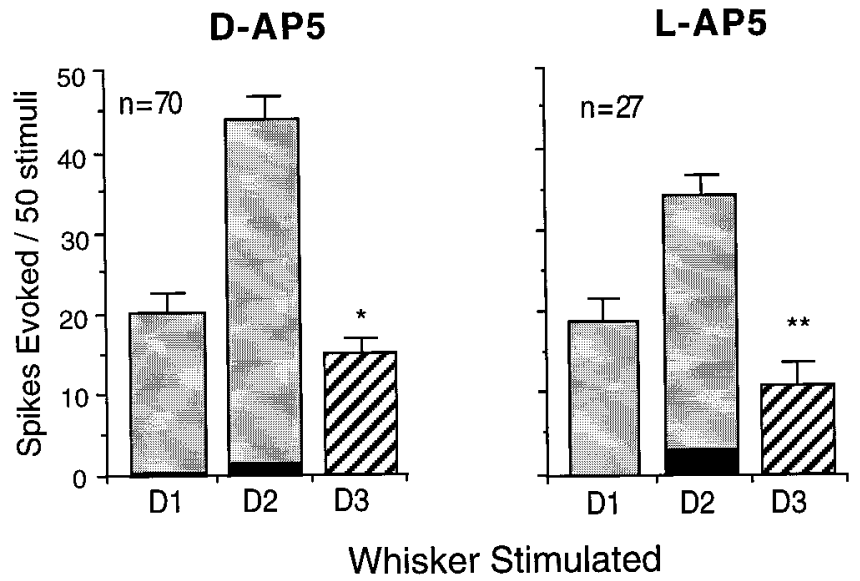

Figure 11. Mean response magnitudes for supragranular cells (layers II-III) of the D2 column for experimental (D-AP5) and control (L-AP5) animals $12-14 \mathrm{hr}$ after stopping superfusion of cortex with active NMDAR antagonist (D-AP5) or inactive isomer (L-AP5). Histograms represent mean responses for 70 cells (experimentals) and 27 cells (controls). Each cell was sampled and analyzed from PSTH data to 50 stimuli applied to each of the D-row whiskers. Error bars represent SEMs. Responses to D3 whisker are significantly different in magnitude as compared with D1 whiskers $\left({ }^{*} p=0.05\right.$ and ${ }^{*} p=0.02$, respectively; Wilcoxon matched-pair sample test). Shortest latency responses (3-8 msec poststimulus) are indicated by black regions within the histograms, which include total responses during $100 \mathrm{msec}$ poststimulus (gray stipple $=$ intact whiskers; diagonal stripes $=$ cut whiskers).

1993). D-AP5 was used at a level that was ineffective in suppressing action potentials generated at latencies $<10 \mathrm{msec}$ poststimulus. Whisker-evoked discharges under identical conditions at these latencies have been identified with monosynaptic thalamocortical discharge (Armstrong-James et al., 1991, 1992; Armstrong-James, 1995) and have been found in a previous study from this laboratory to be dependent for their evocation only on AMPA receptors (Armstrong-James et al., 1993), in common

\section{Layer II/III Cells}
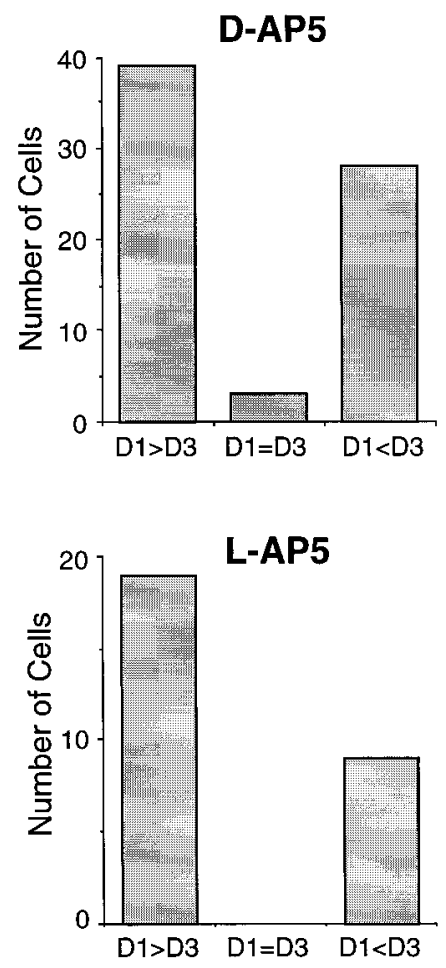

\section{Surround whisker bias}

Figure 12. Surround whisker bias in supragranular (layers II-III) cells. Degree of surround whisker bias for cells in layers II-III of the D2 column evaluated on the basis of numbers of cells responding at greater or lesser response magnitudes to the D1 whisker (paired whisker) relative to the $\mathrm{D} 3$ whisker (cut whisker). $D 1=D 3$ indicates that responses were equal where mean response magnitudes fell between $\pm 5 \%$ of each other. Exposure to D-AP5 reduced the bias caused by pairing of whiskers D1 and D2.

with intracellular findings in the cat in vivo (Salt et al., 1995). Recently, as a first finding it has been shown in the in vitro thalamocortical slice preparation in the mouse that a monosynaptic NMDAR component can be generated to electrical stimulation of the ventrobasal thalamus (Gil and Amitai, 1996). However, those findings relate to responses of layer $\mathrm{V}$ cells, whereas our observations were confined to cells in layers I-IV. Differences in species, stimulation conditions, and in vitro as opposed to in vivo preparations also probably contribute to the different findings.

In one part of this study cells were classified on the basis of duration of action potentials. This was justified on the basis of a bimodal distribution being found that was entirely similar to that found for cells used in previous studies on normal rat cortex. In vitro studies on cortical neurons in rodents have shown that three classes of cells exist: regular spiking, bursting, and fast-spike neurons (McCormick et al., 1985; Agmon and Connors, 1992). Fast-spike neurons with short action potentials were identified as sparsely spiny stellate neurons, whereas the other two types were identified as spiny pyramidal cells. The former have been identified as GABAergic and the latter as excitatory (McCormick et al., 1985; Keller and White, 1987; Connors and Gutnik, 1990; Agmon and Connors, 1992). Interestingly, although we found that fastspike cells were more responsive than slow-spike cells in confir- 
mation of other studies (Simons, 1978; Swadlow, 1989; Armstrong-James et al., 1993), both types of cell exhibited plasticity that was input specific and suppressed by epidural D-AP5 administration. The distributions of these cells by class was unaffected by the infusion procedure, being found to match distributions for normal animals where no drugs were infused.

For layer II-III cells in the same penetrations, a similar quality and degree of plasticity were generated by whisker-pairing in control animals as found for underlying barrel cells. The response bias, however, was incompletely suppressed by D-AP5 $(p<0.042$ for D1 vs D3). One possible reason for this was that the D-AP5 pump was removed about $14 \mathrm{hr}$ before recording to allow for total recovery from any residual AP5 influence. Because SG cells, but not barrel cells, have been shown to exhibit plasticity within $1 \mathrm{~d}$ after whisker pairing (Diamond et al., 1994), 14 hr may be a sufficient time for some plasticity to be newly generated during the period when D-AP5 was not present. Alternatively, plasticity in layers II-III might conceivably be more D-AP5-resistant, although this would seem less likely because D-AP5 was predicted to be at a higher concentration locally in SG layers, and transmission in these layers in rat barrel cortex is dominated by NMDAR transmission, more so than in layer IV (ArmstrongJames et al., 1993) and the concentration of NR1 subunit in SG layers is higher than in layer IV (Rema and Ebner, 1996a).

Unlike previous studies on NMDAR-dependent plasticity of immature sensory cortex (Fox et al., 1996; Brooks et al., 1997), our findings relate to experience-dependent plasticity of fully mature neocortex. As far as we are aware this is the first study to examine adult synaptic modification in cortical neurons directly in this way, although Jablonska and her colleagues (1995) have examined adult mouse barrel cortex plasticity using the deoxyglucose technique after destruction of whisker follicles. They found expansion in the cortical activity patterns corresponding to the "C" row after $7 \mathrm{~d}$ of lesioning all mystacial vibrissa follicles except row C. This plasticity was prevented by Elvax resin implants containing racemic AP5 (Jablonska et al., 1995).

Comparison with the findings for suppression of developmental plasticity suggests that there are at least some common mechanisms for controlling synaptic modifications in adult and developing neocortex. In neonatal animals, VPM axons develop a normal pattern of barrel innervation in rodent cortex, even when cortical activity is completely suppressed during the first postnatal week (Chiaia et al., 1992; Schlaggar et al., 1993). This activity independence suggests that axon arbor distribution is independent of neural activity, in contrast to the development of ocular dominance (OD) columns. However, some features of developmental structural plasticity have been found to be partially dependent on cortical activity over the first week of life in rodents (Schlaggar et al., 1993). The authors found that rearrangements of barrel morphology caused by lesioning a row of vibrissae was prevented by perinatal cortical inactivation by AP5 released from Elvax resin slabs.

Thus, common mechanisms in adults and neonates are suggested by findings that cortical activity suppression prevents functional plasticity in the rat barrel cortex as it does for OD columns in kitten V1 cortex (Reiter and Stryker, 1988). The central feature of most theories is some form of a correlated firing hypothesis, where frequent co-activation of weak inputs on cortical cells leads to synaptic strengthening (Hebb, 1949), which can modify the cortical sensory representation. Analogies with mechanisms underlying LTP are often proposed (for review, see Bear, 1996a) that depend in part on the voltage dependence of the NMDAR.
In contrast with the present findings, it was suggested previously that functional plasticity in sensory cortex, as measured by NMDAR-dependent LTP, comes to an end after the second postnatal week in rat barrel cortex (Crair and Malenka, 1995; Kirkwood et al., 1995). The apparent mismatch with our findings may lie in fundamental differences in mechanisms or alternatively with differences in functionality of in vivo and in vitro preparations. In hippocampal slices, simple synaptic transmission through NMDARs is normally virtually absent (Collingridge and Lester, 1989; Madison et al., 1991; Bear and Malenka, 1994). Similarly, the NMDAR is only activated significantly in neocortical slices when intense postsynaptic activity occurs to sufficiently depolarize the cell, and this is typically achieved by partial blockade of GABA receptors (Artola and Singer, 1987); theoretically the NMDAR then boosts $\mathrm{Ca}^{2+}$ entry to initiate the cascade of enzyme activation required for synaptic modification. The major difference from intact barrel neocortex in vivo is that most normal neurotransmission between cells in cortex, including sensory transmission, is expressed through NMDARs (Armstrong-James et al., 1985, 1993), whereas in untreated slices NMDAR channels are conventionally closed (Collingridge and Lester, 1989). However, a graded relationship between postsynaptic activity, much of which is NMDAR dependent, and plasticity is perfectly reasonable, as suggested by recent models for sensory cortical plasticity (Bienenstock et al., 1982; Benuskova et al., 1994; Bear, 1996a).

A major concern was to establish that our findings were not the result of pathological effects concomitant with our procedures. This influenced our choice of superfusion methodology over an intact dura rather than invasive placement of resins or in-dwelling catheters. The effect of D-AP5 on neuronal plasticity for D2 barrel column cells was evaluated $14 \mathrm{hr}$ after the removal of the minipump containing the drug. In regard to preserved physiological function, the findings show that the neurons studied had an overall response profile and distribution entirely similar to controls for which superfusion of inactive isomer of L-AP5 was used. Second, the findings for receptive field bias exhibited by control neurons matched those found for previous studies on normal animals in which identical whisker-pairing experiments were performed, and D2 barrel column cells were examined without minipump delivery of drugs (Diamond et al., 1993; ArmstrongJames et al., 1994). In addition there were no gross changes in NMDA receptor density within the D2 column as witnessed by NMDAR1 immunoreactivity. We checked this because of the clustering of NMDA receptors demonstrated by Rao and Craig (1997) along the dendrites of hippocampal cells in culture after 7-14 d periods of exposure to D-AP5. We conclude that our technique had no detectable deleterious effect on overall excitability or neuronal function. However, the finding of Rao and Craig (1997) has relevance to our observation that response magnitudes in animals exposed to D-AP5 superfusion increase for layer II/III cells. It is quite possible that NMDAR subsynaptic clustering was induced by the drug and indiscriminately potentiated all excitatory synapses. However, in addition we found that spontaneous activity was decreased only in layers II/III. More research is required to determine whether such an effect may be unique to NMDARs at particular types of synapses.

The concentration of D-AP5 we used was 10- to 100-fold less than that used in Elvax resins for several days for examining developmental cortical plasticity in rodents and cats (Schlaggar et al., 1993; Jablonska et al., 1995; Brooks et al., 1997). However, the concentration we used was adequate to suppress virtually all evoked activity of neurons in layers II-III. This was not surprising 
because in a previous iontophoretic study on barrel neurons (Armstrong-James et al., 1993) D-AP5 at concentrations specific for suppression of NMDAR activity also suppressed virtually all whisker-evoked responses of neurons in layers II-III. However, layer IV (barrel) neurons in the same study were found to generate virtually all of their earliest spikes ( $<10 \mathrm{msec}$ latency) through AMPA receptors; later spikes were almost totally NMDAR dependent. Because in the present study the concentration of AP5 was adjusted to leave short-latency (AMPARdependent) responses unaffected over trials of several hours, it is reasonable to suggest that the concentration of D-AP5 was fairly specific for NMDAR suppression within layer IV.

Even allowing for specificity of D-AP5, however, in this study the interpretation of the findings can be viewed from the standpoint of suppression of neuronal responses per se, i.e., activity suppression rather than an effect that can be interpreted as specific to NMDAR activity suppression (Miller et al., 1989; Armstrong-James et al., 1993), because transmission of sensory information in both visual cortex (Tsumoto et al., 1987) and barrel cortex (Armstrong-James et al., 1993) is substantially NMDAR dependent. This alternative interpretation was given by Miller et al. (1989) for findings by Kleinschmidt et al. (1987) in which ocular dominance plasticity for kitten striate cortical neurons was disrupted using intracortical infusion at a point source of 5-50 mM D-AP5 to achieve target concentrations of $\sim 10-100$ $\mu \mathrm{M}$ on sampled cells showing plasticity suppression. These concentrations are in the same range as those found to be adequate for NMDAR activity suppression in this study.

\section{REFERENCES}

Agmon A, Connors BW (1992) Correlation between intrinsic firing patterns and thalamocortical synaptic responses of neurons in mouse barrel cortex. J Neurosci 12:319-329.

Armstrong-James M (1995) The nature and plasticity of sensory processing within adult rat barrel cortex. Cerebral cortex, Vol 11, Chap 8, The barrel cortex of rodents (Jones EG, Diamond IT, eds), pp 333-373. New York: Plenum.

Armstrong-James M, Callahan CA (1991) Thalamocortical processing of vibrissal information in the rat. II. The contribution of ventroposterior medial thalamic (VPm) neurones. J Comp Neurol 303:211-224.

Armstrong-James M, Fox K (1987) Spatio-temporal divergence and convergence in rat SI "barrel" cortex. J Comp Neurol 263:265-281.

Armstrong-James M, George MJ (1988) The influence of anaesthesia on spontaneous activity and receptive field size of single units in rat Sm1 neocortex. Exp Neurol 99:369-387.

Armstrong-James M, Millar JM (1979) Carbon fibre microelectrodes. J Neurosci Methods 1:279-287.

Armstrong-James M, Fox K, Millar JM (1980) A method for etching the tips of carbon fibre microelectrodes. J Neurosci Methods 2:431-432.

Armstrong-James M, Caan AW, Fox K (1985) Threshold effects of $N$-methyl-D-aspartate (NMDA) and 2-amino 5-phosphono valeric acid (2APV) on the spontaneous activity of neocortical single neurones in the urethane anaesthetised rat. Exp Brain Res 60:209-213.

Armstrong-James M, Callahan CA, Friedman M (1991) Thalamocortical processing of vibrissal information in the rat. I. Intracortical origins of surround but not center-receptive fields of layer IV neurons in the rat SI barrel field cortex. J Comp Neurol 303 193-210.

Armstrong-James M, Fox K, Das Gupta A (1992) Flow of excitation within rat barrel cortex on striking a single vibrissa. J Neurophysiol 68:1345-1358.

Armstrong-James M, Welker E, Callahan CA (1993) The contribution of NMDA and non-NMDA receptors to fast and slow transmission of sensory information in the rat SI barrel cortex. J Neurosci 13:2149-2160.

Armstrong-James M, Diamond ME, Ebner FF (1994) An innocuous bias whisker use in adult rats modifies receptive fields of barrel cortex neurons. J Neurosci 14:6978-6991.

Artola A, Singer W (1987) Long-term potentiation and NMDA receptors in rat cortex. Nature 330:649-652.
Ascher P, Nowak L (1987) Electrophysiological studies of NMDA receptors. Trends Neurosci 10:284-288.

Bear MF (1996a) A synaptic basis for memory storage in the cerebral cortex. Proc Natl Acad Sci USA 93:13453-13459.

Bear MF (1996b) NMDA-receptor-dependent synaptic plasticity in the visual cortex. Prog Brain Res 108:205-218.

Bear MF, Malenka RC (1994) Synaptic plasticity: LTP and LTD. Curr Opin Neurobiol 4:389-399.

Benuskova L, Diamond ME, Ebner FF (1994) Dynamic synaptic modification threshold: computational model of experience-dependent plasticity in adult rat barrel cortex. Proc Natl Acad Sci USA 91:4791-4795.

Bienenstock EL, Cooper LN, Munro PW (1982) Theory for the development of neuron selectivity: orientation specificity and binocular interactions in visual cortex. J Neurosci 2:32-48.

Bliss TVP, Collingridge GL (1993) A synaptic model of memory: longterm potentiation in the hippocampus. Nature 361:31-39.

Brooks WJ, Petit TL, LeBoutillier JC (1997) Effect of chronic administration of NMDA antagonists on synaptic development. Synapse 26:104-113.

Chiaia NL, Fish SE, Bauer WR, Bennett-Clarke CA, Rhoades RW (1992) Postnatal blockade of cortical activity by tetrodotoxin does not disrupt the formation of vibrissa-related patterns in the rat's somatosensory cortex. Dev Brain Res 66:244-250.

Collingridge GL, Lester RAJ (1989) Excitatory amino acid receptors in the vertebrate central nervous system. Pharmacol Rev 40:145-210.

Connors BW, Gutnik MJ (1990) Intrinsic firing patterns of diverse neocortical neurons. Trends Neurosci 13:99-104.

Crair MC, Malenka RC (1995) A critical period for long-term potentiation at thalamocortical synapses. Nature 375:325-328.

Delacour J, Houcine O, Talbi B (1987) "Learned" changes in the responses of the rat barrel field neurons. J Neurosci 23:63-71.

Diamond ME, Armstrong-James M, Budway MJ, Ebner FF (1992) Somatic sensory responses in the rostral sector of the posterior group $(\mathrm{POm})$ and in the ventral posterior medial nucleus (VPM) of the rat thalamus. J Comp Neurol 318:462-476.

Diamond ME, Armstrong-James M, Ebner FF (1993) Experiencedependent plasticity in adult rat barrel cortex. Proc Natl Acad Sci USA 90:2082-2086.

Diamond ME, Huang W, Ebner FF (1994) Laminar comparison of somatosensory cortical plasticity. Science 265:1885-1888.

Dykes R (1997) Mechanisms controlling neuronal plasticity in somatosensory cortex. Can J Physiol Pharmacol 75:535-545.

Fox K, Armstrong-James M (1986) The role of the anterior intralaminar nuclei and $N$-methyl-D-aspartate receptors in the generation of spontaneous bursts in neocortical neurones. Exp Brain Res 63:505-518.

Fox K, Schlaggar BL, Glazewski S, O'Leary DDM (1996) Glutamate receptor blockade at cortical synapses disrupts development of thalamocortical and columnar organization in somatosensory cortex. Proc Natl Acad Sci USA 93:5584-5589.

Gil Z, Amitai Y (1996) Adult thalamocortical transmission involves both NMDA and non-NMDA receptors. J Neurophysiol 76:2547-2554.

Hand PJ (1982) Plasticity of the rat cortical barrel system. In: Changing concepts of the nervous system (Morrison AR, Strick PL, eds), pp 49-68. New York: Academic.

Hebb DO (1949) The organization of behaviour. New York: Wiley.

Hicks TP, Kaneko T, Metherate R, Oka J-I, Stark CA (1991) Amino acids as transmitters of synaptic excitation in neocortical sensory processes. Can J Physiol Pharmacol 69:1099-1114.

Jablonska B, Gierdalski M, Kublik A, Skangiel-Kramska J (1995) Partial blocking of NMDA receptors restricts plastic changes in adult mouse barrel cortex. Behav Brain Res 66:207-216.

Jablonska B, Kossut M, Skangiel-Kramska J (1996) Transient increase of AMPA and NMDA receptor binding in the barrel cortex of mice after tactile stimulation. Neurobiol Learn Mem 66:36-43.

Keller A, White EL (1987) Synaptic organization of GABAergic neurons in the mouse SmI cortex. J Comp Neurol 262:1-12.

Killackey HP, Belford G, Ryugo R, Ryugo DK (1976) Anomalous organization of thalamocortical projections consequent to vibrassae removal in the newborn rat and mouse. Brain Res 104:309-315.

Killackey HP, Ivy GO, Cunningham TJ (1978) Anomalous organization of SM1 somatotopic map consequent to vibrissae removal in the newborn rat. Brain Res 155:136-140.

Kirkwood A, Lee H-K, Bear MF (1995) Co-regulation of long-term potentiation and experience-dependent synaptic plasticity in visual cortex by age and experience. Nature 375:328-331. 
Kleinschmidt A, Bear MF, Singer W (1987) Blockade of NMDA receptors disrupts experience-dependent plasticity of kitten striate cortex. Science 238:355-358.

Kossut M, Glazewski S, Siucinska E, Skangiel Kramska J (1993) Functional plasticity and neurotransmitter receptor binding in the vibrissal barrel cortex. Acta Neurobiol Exp (Warsz) 53:161-173.

Madison DV, Malenka RC, Nicoll RA (1991) Mechanisms underlying long-term potentiation of synaptic transmission. Annu Rev Neurosci 14:379-397.

Masino SA, Frostig RD (1995) Cortical plasticity assessed with intrinsic signal imaging in rat barrel cortex. Soc Neurosci Abstr 21:123.

McCasland JS, Carvell GE, Simons DJ, Woolsey TA (1991) Functional asymmetries in the rodent barrel cortex. Somatosens Mot Res 8:111-116.

McCormick DA, Connors BW, Lighthall JW, Prince DA (1985) Comparative electrophysiology of pyramidal and sparsely spiny stellate neurons of the neocortex. J Neurophysiol 54:782-806.

Melzer P, Smith CB (1997) Plasticity of cerebral metabolic whisker maps in adult mice after whisker follicle removal-I. Modifications in barrel cortex coincide with reorganization of follicular innervation. Neuroscience 83:27-41.

Miller KD, Chapman B, Stryker MP (1989) Visual responses in adult cat visual cortex depend on $N$-methyl-D-aspartate receptors. Proc Natl Acad Sci USA 86:5183-5187.

O'Leary DDM, Ruff NL, Dyck RH (1994) Development, critical period plasticity, and adult reorganizations of mammalian somatosensory systems. Curr Opin Neurobiol 4:535-544.

Pidoux B, Diebler MF, Savy C, Farkas E, Verley R (1980) Cortical organization of the postero-medial barrel-subfield in mice and its reorganization after destruction of vibrissal follicles after birth. Neuropathol Appl Neurobiol 6:93-107.

Rao A, Craig AM (1997) Activity regulates the synaptic localization of the NMDA receptor in hippocampal neurons. Neuron 19:801-812.

Reiter HO, Stryker MP (1988) Neural plasticity without postsynaptic action potentials: less active inputs become dominant when kitten visual cortical cells are pharmacologically inhibited. Proc Natl Acad Sci USA 85:3623-3627.

Rema V, Ebner FF (1996a) Postnatal changes in NMDAR1 subunit expression in the rat trigeminal pathway to barrel field cortex. J Comp Neurol 368:165-184.
Rema V, Ebner FF (1996b) The effects of prenatal ethanol on barrel field cortex plasticity are exacerbated by postnatal sensory deprivation. Soc Neurosci Abstr 22:470.

Ryugo DK, Ryugo R, Killacky HP (1975) Changes in pyramidal cell density consequent to vibrissae removal in the newborn rat. Brain Res 96:82-87.

Sachdev RS, Lu SM, Wiley RG, Ebner FF (1998) The role of the basal forebrain cholinergic projection in somatosensory cortical plasticity. J Neurophysiol 79:3216-3228.

Salt TE, Eaton SA (1988) Function of non-NMDA receptors and NMDA receptors in synaptic responses to natural somatosensory stimulation in the ventrobasal thalamus. Exp Brain Res 77:646-652.

Salt TE, Meier CL, Seno N, Krucker T, Herrling PL (1995) Thalamocortical and corticocortical excitatory postsynaptic potentials mediated by excitatory amino acid receptors in the cat motor cortex in vivo. Neuroscience 64:433-442.

Schlaggar BL, Fox K, O'Leary DDM (1993) Postsynaptic control of plasticity in developing somatosensory cortex. Nature 364:623-626.

Simons DJ (1978) Response properties of vibrissa units in rat SI somatosensory neocortex. J Neurophysiol 41:798-820.

Siucinska E, Kossut M (1994) Short term changes of cortical body maps following partial vibrissectomy in adult mice. Acta Neurobiol 54:345-352.

Swadlow HA (1989) Efferent neurons and suspected interneurons in S-1 vibrissa cortex of the awake rabbit: receptive fields and axonal properties. J Neurophysiol 62:288-308.

Tsumoto T, Hagihara K, Sato H, Hata Y (1987) NMDA receptors in visual cortex of young kittens are more effective than those of adult cats. Nature 327:513-514.

Wong-Riley MTT, Welt C (1980) Histochemical changes in cytochrome oxidase of cortical barrels after vibrissal removal in neonatal and adult mice. Proc Natl Acad Sci USA 77:2333-2337.

Woolsey TA, Wann JR (1976) Areal changes in mouse cortical barrels following vibrissal damage at different postnatal ages. J Comp Neurol 170:53-66.

Woolsey TA, Van der Loos H (1970) The structural organization of layer IV in the somatosensory region (S1) of mouse cerebral cortex. The description of a cortical field composed of discrete cytoarchitectonic units. Brain Res 17:205-242. 